\title{
Resisting Best-Practice in Australian Practice-Based Jazz Doctorates
}

\author{
Christopher Coady and Michael Webb \\ 1 Conservatorium Road, Sydney NSW 2000, Australia \\ christopher.coady@sydney.edu.au, michael.webb@sydney.edu.au
}

Recent research on practice-based doctorates in Australia has revealed an institutional preference for 'theorised' research approaches aimed at situating studies of practice within established academic paradigms. In this article we examine how the aim of communicating with artistic peers steers the research design and the production of text-based artefacts for a group of practice-based doctoral students working on jazz topics $(n=11)$ away from theorised approaches and towards what is commonly referred to as a 'commentary' approach. This finding reveals the extent to which the values of an artistic community can influence the scope of what is discussed within practice-based doctorates and highlights the need for ongoing discussion related to how such values might best interface with what institutions view as best-practice research frameworks.

\section{Introduction}

The nature of doctoral jazz research in Australia is changing. Where once the landscape of Australian jazz PhD and DMA research was dominated by those who sought to produce knowledge new to a specific academic discipline, such as anthropology, sociology, history, musicology or pedagogy (see Whiteoak, 1993; Harrison, 1999; Stevens, 2000; Franklin, 2001; Sugg, 2001; Freeman, 2006), recent doctoral work has shifted towards questions related to how individual artists might grow through the exploration of their own jazz practice (see Hodges, 2008; Barker 2010; Burke, 2013; Williamson, 2013; Evans, 2014; Haywood, 2014; Holgate, 2014). Students working within this new paradigm concentrate on the development of an individual voice and innovate new approaches to jazz practice that are then demonstrated through both creative work (i.e. recording portfolios and/or music scores) and text-based artefacts (i.e. theses, dissertations, or exegeses).

This approach to doctoral research moves the student researcher from the position of observer to subject and has variously been referred to as 'practice-based' or 'practiceled' research (Candy, 2006, p. 3; Draper \& Harrison, 2011, p. 88). Linda Candy draws a distinction between these terms, referring to practice-based research as research in which knowledge is demonstrated 'through creative outcomes', and practice-led research as research 'concerned with the nature of practice' (Candy, 2006, p. 1). While the umbrella term 'artistic research' is increasingly used in discussion of approaches that shift between the two arenas identified by Candy in the European context (Borgdorff, 2011; Kjørup, 2011), we have chosen to use the term 'practice-based' in this article due to the term's predominance in two major research studies surveying doctoral research with a creative component in Australia (Paltridge et al., 2011; Paltridge et al., 2012). 
The growth of practice-based research in Australian tertiary institutions is certainly not unique to doctoral students working within the field of jazz studies. Draper and Harrison (2011) have, for instance, discussed the work of practice-based students working across a variety of musical genres within the new DMA program at the University of Queensland. Paltridge et al.'s (2011) survey of performing arts doctorates throughout Australia has in turn revealed widespread interest in practice-based approaches across the fields of music, dance and visual arts. Beyond the realm of visual and performing arts, practice-based research has a long history in Australian tertiary creative writing programs, much of which has been documented in the Australian journal Text: Journal of Writing and Writing Courses, launched in 1997.

While a diversity of particular approaches and outputs can be found when examining practice-based doctoral submissions at the disciplinary level (see for example Armstrong, 2002; Fenton, 2007; Barker, 2010), a belief that tends to unite disciplines is that the textbased artefact and the creative work of a submission should be woven together in a way that interfaces traditional 'academic' knowledge with knowledge grounded in practice (Milech \& Schilo, 2004; Stock, 2009; Draper \& Harrison 2010, p. 3; Hamilton \& Jaaniste, 2010; Paltridge et al., 2011, p. 250). Milech and Schilo have envisioned this act as 'research[ing] a single question in two languages' and point to the ways in which shaping a creative work through the study of theory and an expository work through one's experience in practice tends to result in a better understanding of generic principles of research (Milech \& Schilo, 2004, para. 21). Stock's discussion of supervisory practice in relation to dance similarly argues that 'appropriate exegetical perspectives seem best served by an ongoing dialogic process in which the practice develops emergent theory... and reading/viewing inform aspects of the practice' (Stock, 2009, p. 6). Less desirable in the minds of Milech and Schilo is what they refer to as a 'commentary model' in which 'the exegesis is conceived as an explication of, or comment on, the creative production' (Milech \& Schilo, 2004, para. 19). Of particular concern for these authors is the way such a model makes it 'difficult to justify to research students the function of the exegesis as anything more than compliance with the requirements of contemporary academic structures' (Milech \& Schilo, 2004, para. 20).

We begin this article by surveying debates over the nature and aim of the text-based artefact in practice-based doctoral programs and illuminate how a preference for theorised reporting of creative practice in line with the 'two languages' approach described by Milech and Schilo (2004) aligns with an institutional need to 'situate' practice-based doctorates in relation to traditional research outputs (Biggs \& Büchler, 2008, p. 6; Wilson, 2011). We then present data from a focus group comprised of current Australian jazz PhD and DMA candidates $(n=11)$ that reveal a set of research aims steering students away from theorized exegeses and towards commentary models. In particular, our focus group data highlight how a desire to deliver innovative ideas back to communities of artistic peers influences the scope of these participants' practice-based doctoral work. We end by discussing how an awareness of this goal can help tertiary educators understand resistance to what are increasingly being viewed as best practice models for artistic research and scaffold thinking about the presumed strength of particular styles of exegetical writing. 


\section{'Situating' Artistic Research and the Emergence of the Theoretical Exegesis}

In a recent essay addressing practice-based research developments within several European arts institutions, Biggs and Karlsson point to the dangers inherent in using criteria for assessing research significance that come from outside the communities in which artistic products are consumed, claiming: 'Such an enterprise will always be doomed to failure since there is only a partial overlap between the interests of the academic community and the professional arts community' (Biggs \& Karlsson, 2011, p. 423). Henk Borgdorff, chair of the 'Research in the Arts' research group at the Royal Conservatoire in The Hague, has in turn stressed the fact that 'the outside world... plays a central role in formulating the research agenda, formulating the direction the research has to take, evaluating the outcomes of the research, and assessing the quality' of practice-based projects (Borgdorff, 2012 , p. 179). Several other authors interested in the relationship between practice-based research and the academy have voiced similar concerns (see for instance: Biggs at al., 2010; Biggs \& Büchler, 2011; Macleod \& Chapman, 2014).

Nevertheless, from the handful of research studies undertaken on the experience of Australian higher degree candidates engaged in practice-based research, it appears to be common for traditional markers of significance to outweigh what might be held to be significant contributions to the wider artistic community during moments of assessment. Paul Draper and Scott Harrison's study of the student experience within the new DMA program at the Queensland Conservatorium for instance, demonstrates how the confirmation process for candidates continues 'to mirror a traditional approach where the written document, its research questions, literature review and method attract the most scrutiny, and much less so... potentially innovative portfolio possibilities' (Draper \& Harrison, 2011, p. 97). Dally et al.'s examination of Fine Art PhDs across Australia in turn finds that despite the fact that nearly all examiners agree on the idea that the exhibition forms 'the core of the research,' in the cases where PhD submissions are found wanting, they are almost always assessed so on the basis of deficits within the thesis component of the submission (Dally et al., 2004, pp. 149-150).

Such institutional focus on the traditional written component of practice-based doctoral work has in turn led to a good deal of thought over what might constitute appropriate exegetical design. Paltridge et al.'s (2011) survey of practice-based doctoral programs across Australia confirms the presence of what Milech (2006) has identified as three general approaches to practice-based doctoral writing: the 'context' model, 'commentary' model and 'research question' model (Paltridge et al., 2011, p. 250). The first two of these approaches centre on telling the story of a creative work's development and differ mainly in the extent to which they argue for the significance of the creative work in relation to one's own artistic development (Paltridge et al., 2011, pp. 250-251). That is, while both the 'context' and 'commentary' models describe the historical background and social forces woven through a creative work, the 'commentary' model makes clear through pre- and post-reflection how creative processes themselves have changed over the course of a practice-based doctorate (Paltridge et al., 2011, p. 251). The 'research-question' model in contrast aims to 'honour two masters ... the disciplinary forms and languages of fields of study relatively new to Australian universities, and the understanding of research 
embodied in the genre of the traditional written thesis' (Milech \& Schilo, 2004, para. 23). Simply put, the 'research-question' model requires students to identify and articulate a gap in knowledge in a particular creative field and produce creative work(s) that can then be described as filling this gap (Milech \& Schilo, 2004, para. 23).

Evidence of a preference for the 'research-question' model in practice-based doctoral submissions across Australia is slowly coming to light (Paltridge et al., 2012; Ravelli et al., 2013). Paltridge et al.'s (2012) examination of 36 practice-based doctoral theses from a range of Australian institutions revealed a tendency for students to mirror the 'typical macrostructure' of 'an Introduction-Methods-Results-Discussion (IMRD) dissertation' when crafting their exegeses (Paltridge et al., 2012, p. 4). In accounting for such results, the authors argue:

The main centripetal force at stake here is the underlying functions of a doctoral thesis, such as the need to contextualize the research, the need to engage with theory, the need to place the research within a broader field, and the need to demonstrate the way/s in which the doctoral project moves the field forward. (Paltridge et al., 2012, p. 10)

In further discussion of the same data set, Ravelli et al. (2013) have argued bluntly that institutional inertia - i.e. 'what institutions have accepted as instances of doctoral theses in the visual and performing arts' - has led to 'anxiety often felt by students and supervisors as to how a thesis "should" be written' (Ravelli et al., 2013, p. 417). This institutional pressure impacts '[the] sense of agency on the part of the authors/artists' who may wish to explore 'different typical relations as a way of opening up the semiotic space [i.e. the relationship between the creative and text-based artefacts]' (Ravelli et al., 2013, p. 417). Such comments echo the findings of Wilson (2011), who explains in her history of Australian creative arts research policy that 'while individual universities may have sought to give effect to the "notion that all academics should be treated equally" ... these institutions were mindful that to deviate too far from national performance measures, heavily skewed towards scientific definitions and expectations of research, could have significant financial implications' (Wilson, 2011, p. 68).

Embracing a 'research-question' model of exegetical writing therefore carries with it clear benefits in terms of helping practice-based research gain purchase within what Biggs and Büchler have referred to as the 'comparative competitive environment' of academia (Biggs \& Büchler, 2008, p. 6). Yet, as our focus group data shows, a subset of practice-based doctoral students engaged in jazz topics seem unconcerned with such positioning. Instead, these students pursue research methodologies and artefacts that place communication with their artistic communities at the heart of their research strategies. An examination of student comments explaining this choice helps illuminate the mechanics underpinning Borgdorff's view that 'the outside world ... plays a central role in formulating the research agenda [of practice-based projects]' (Borgorff, 2012, p. 179) and demonstrates a rift between what is viewed as best practice research from the perspective of one group of jazz practitioners and the perspective of the institution.

\section{Focus Group Overview}

The focus group session for this study was held at the Sydney Conservatorium of Music during the second half of a one-day symposium titled Negotiated Research Paradigms and 
the Jazz PhD in Australia. Participants were recruited through an email approach approved by the University of Sydney Human Research Ethics Committee. As part of this approach, it was made clear that prospective participants would need to be currently enrolled in either an Australian PhD or DMA program and working on a 'jazz topic.' While our intent was to recruit widely from a spectrum of Australian tertiary programs, the vast majority of our participants were candidates from the University of Sydney $(n=10)$ with one from the University of New South Wales $(n=1)$. The data we present, and the practice-based bent of nearly all participants' projects, is therefore rather specific to the University of Sydney experience. Nevertheless, this specificity carries with it a level of comprehensiveness in terms of tracing the dynamics of a particular post-graduate program that could not have been achieved with a more diverse cohort of participants.

The focus group discussion lasted one hour and was loosely organised around two broad topics: (1) 'The development of thesis topics' and (2) 'Research significance and rigour'. General prompt questions were developed beforehand in relation to these broad discussion topics and follow up questions were asked during the course of the focus group in accordance with emergent themes. The focus group format was specifically chosen for this project in order to grant participants greater control over the discussion and the data therein. Specifically, open-ended discussion allowed participants to steer the conversation into those topics most relevant to them, even if such topics did not appear as part of the organizing frame (see Cohen \& Manion, 1994, pp. 287-288; Stewart, Rook \& Shamdasani, 2007 , pp. 42-43 for precedent). Data was then transcribed and coded in accordance with a general inductive approach (Thomas, 2006) and two overarching themes emerged from this analysis: Community Oriented Research Aims and Community Oriented Research Processes.

\section{Focus Group Results}

\section{Community Oriented Research Aims}

Discussion of research 'significance' amongst participants tended to confirm Borgdorff's view that making an impact in the 'outside world' serves as a core aim of practicebased research (Borgdorff, 2012, p. 179). In particular, the sharing of new procedural knowledge with communities of practitioners arose as a specific goal for two participants who highlighted the way such knowledge could, in their words, 'create... aesthetic communities' or 'broaden the scope' of aesthetic practice within these communities. An aligned concept emerged in the comments of a participant who spoke about the importance of documenting 'how things are developing' within a particular community of practitioners with an eye towards helping community members wrestle with the limitations imposed by 'genres and monickers.' Still other participants located their project's significance in relation to how their individual position within their artistic community might be reified or improved. As one stated:

I'm trying to develop a solo voice for myself... I feel like that's the outcome that I'm trying to get. A voice of my own, on my own, that's distinctive enough to feel like some sort of legitimacy from that... Obviously, most of the time the point of jazz is 
to play and interact with other people but it's just like this one thing that I do want to have under my belt, which I prob - because I have to eat and stuff.

Such a reflection on improved economic positioning in connection with the comments relating to stewardship above speak to the idea that research impact was understood by many in this group in terms of how well research findings could be integrated into the artistic community towards which they were oriented.

This understanding was further confirmed through the ways in which participants tended to set up the parameters of their topics. As a participant stated:

If I felt that something could map on or be borne out practically at every stage, that's been something that's really guided what's genuinely helpful for me and then helped me also jettison things that haven't been so helpful.

This same participant explained that his candidature began with a fascination with 'embodied cognition' but then later changed course:

The act of trying to develop a strong methodology for a project ended up stripping away a lot of those peripherals, until such time as the entire - the research itself, even the contextual research, became very practically focused.

These two statements about 'practicality' stand at odds with the dialogical aim of practice-based research endorsed by Milech and Schilo (2004) and Stock (2009). That is, participants' references to 'practicality' seem to ascribe parameters to the project that are firmly within the arena of practice with less interest in the development of theoretical models that might hold implications beyond the 'practical' realm. In a similar vein, another participant spoke of centring his enquiry on practice from the very beginning and engaging with 'different research fields' as 'something that came almost as an afterthought of engaging in the process itself, rather than something that was planned out from the outset.'

\section{Community Oriented Research Processes}

The aim of developing and sharing new artistic processes in turn can be seen to inform what participants conceived to be effective research methodologies and appropriately designed text-based artefacts. Conceptions of research 'methodology' as a set of procedures aimed at developing one's artistic voice in collaboration with a particular community of practitioners was made most overt in the comments of two participants working within quite different geographic locations. The first was a regionally-based student enrolled in a PhD in composition that focused on the phenomena of 'collaboration and ... the hierarchies of interaction' that took place within her works. She spoke of beginning her project with a 'template' for collaborating with specific ensembles and her intent 'to follow that to the dot ... for every song.' Yet almost from the start, she was forced to rethink her template, as she explains in the following quote: 
Someone couldn't be there and that didn't go very well. This collaboration went really well, so we ended up writing more pieces together... Then I wanted to lyrically write with someone but I didn't have a rubric for that... so things had to change, as the music informed. As all the collaborations changed, all my methodology had to change.

Such comments indicate the impact this student's community of peers had in shaping what she viewed as the methodology and creative outcomes of her doctoral work. Indeed, as the student articulated later in the session: 'We're used to asking our peers about and trialling things. We trial lots of stuff with our friends and colleagues, musically.'

This student's position was echoed in the comments of another participant working on new improvisational processes within the Melbourne jazz scene:

For me, my methodology seems to sort of - it wraps around me. It's kind of in the ether a little bit because, with my particular topic, it's about analysing these notes, experimenting with these notes, musical experiments, trying out data, keeping what's good, throwing out what's bad - with no real clear - until the pieces start to come together.

Here the role of the student's community of practitioners is implicitly referred to in reference to 'musical experiments' and 'trying out data' - a point he later clarified through the claim that 'We are often operating in communities. All of us test our ideas with our colleagues and peers in ensembles all the time.'

This view of one's community of practitioners lying at the heart of the research process is then reflected in the sort of written exegesis participants in the study tended to pursue. That is, several participants discussed the purpose of the text-based artefact in terms of giving the creative processes that they discovered through practice-based methodologies 'some possibility of travel.' One participant for instance spoke of the written component of his PhD as a way of 'invit[ing] readers and... non-practitioners' into the 'processes' explored in his creative work. Another participant spoke of the 'clarity of communication' academic writing offered for transmitting artistic ideas to other jazz practitioners - a central feature of jazz cultural practice that had existed, in the mind of this participant, 'for all the music's history.' Further thoughts on this topic highlighted the way 'bringing it [discussions of jazz practice] to the academy... pioneered a kind of language' for the discussion of procedural issues. Such comments link strongly with the ways in which participants conceive of research significance and seem to frame the text-based artefact primarily as a delivery vehicle for intellectual ideas vetted outside University walls.

\section{Conclusions}

The research aims and the perceived audience for research outcomes expressed by participants in this study articulates a level of conflict with what many view to be the preferred model of practice-based research in Australia (Milech \& Schilo, 2004; Stock, 2009; Hamilton \& Jaaniste, 2010). The work of Milech and Schilo (2004) and Stock (2009) for instance clearly place into a hierarchical relationship those projects seeking to document and comment on artistic practice and those that engage established fields of academic enquiry in setting up interrogations of practice. Hamilton and Jaaniste (2010) have in turn 
argued against projects concerned solely with documenting the development of artistic practice, favouring instead what they refer to as a 'connectivity model' in which 'academic objectivity and personal reflection' are integrated in order to connect creative processes with 'broader theoretical and practical contexts' (Hamilton \& Jaaniste, 2010, p. 39). The fact that students in this study seem unconcerned with engaging 'broader theoretical and practical contexts' and more concerned with documenting and sharing creative process with their peers, means that their projects are out of step with such assertions of bestpractice research strategy.

It is not our intent to argue that the research approach documented in this study provides a better model for undertaking practice-based research. Our data do illuminate however, the powerful role peers of jazz practitioners play in shaping the research methodologies and the text-based artefacts pursued by practice-based doctoral candidates. Borgdorff's (2012) assertions regarding the influence artistic communities exert over practice-based research is shown in this study to work against the establishment of theoretical links that might situate practice-based jazz doctorates more firmly within academic traditions of thought. The journey of the participant who spoke of 'stripping away... peripherals' in collaboration with his peers 'until such time as the entire... research, became very practically focused" provides a neat summary of this phenomenon.

Whether or not one agrees with this approach to doctoral research, its frequent and increasing use amongst Australian jazz doctoral candidates begs us to consider the ways in which the research aims members of the arts community bring with them to the academy are valued. The research approaches utilised by students in this study are not embraced because of their easy 'compliance with the requirements of contemporary academic structures' (Milech \& Schilo, 2004, para. 20), but because they are seen to be the best way of delivering innovative ideas back to peers in the jazz community. Indeed, for the jazz practitioners in our study, a culture of sharing innovative processes seems to drive the desire to engage in practice-based research at least as much as the aim of transforming one's artistic voice or the aim of contributing to standing academic discourse.

As practice-based jazz research continues to develop in Australia - and as practicebased research projects are increasingly submitted for examination - the conflict identified between institutionally preferred models of exegetical writing and the commentary model preferred by jazz practitioners will likely come to a head. Understanding that commitment to the commentary model is linked to the central aim jazz practitioners bring with them to the University demonstrates that there needs to be an ongoing dialogue around how best to address this issue. At the very least, an acknowledgement that different exegetical models carry with them different, and at times competing strengths needs to be more fully integrated into discussions of ideal exegetical format. Broadening discussion from how an exegesis might best situate practice-based research within the academy to how an exegesis might best impact the aesthetic world in which practitioners operate may serve as useful starting point for such discussions.

\section{References}

ARMSTRONG, K. (2002) Towards an Ecosophical Praxis of New Media Space Design. (Unpublished PhD Thesis). Queensland University of Technology. 
BARKER, S. (2010) 'Scattering Rhythms': The Koreanisation of the Western Drumset. (Unpublished PhD Thesis). University of Sydney.

BIGGS, M. \& BÜCHLER, D. (2008) Eight criteria for practice-based research in creative and cultural industries. Art, Design \& Communication in Higher Education, 7(1), 5-18.

BIGGS, M. \& BÜCHLER, D. (2011) Communities, values, conventions and actions. In M. Biggs \& H. Karlsson (Eds.), The Routledge Companion to Research in the Arts (pp. 82-98). New York: Routledge.

BIGGS, M., BÜCHLER, D., ROCCO, R \& SCHJERVEN, C. (2010) The production of academic research and some barriers to academicization in the creative and performing arts. In L. Gómez, D. Belenguer \& I. Torres (Eds.), Proceedings of ICERI2010 Conference (pp. 378-385). Madrid: International Association of Technology, Education and Development.

BIGGS, M. \& KARLSSON, H. (2011) Evaluating quality in artistic research. In M. Biggs \& H. Karlsson (Eds.), The Routledge Companion to Research in the Arts (pp. 405-424). New York: Routledge.

BORGDORFF, H. (2011) The production of knowledge in artistic research. In M. Biggs \& H. Karlsson (Eds.), The Routledge Companion to Research in the Arts (pp. 44-63). New York: Routledge.

BORGDORFF, H. (2012) The Conflict of the Faculties: Perspectives on Artistic Research and Academia. Leiden: Leiden University Press.

BURKE, R. (2013) Analysis and Observation of Pre-Learnt and Idiosyncratic Elements in Improvisation: A Reflective Study in Jazz Performance. (Unpublished PhD Thesis). Monash University.

CANDY, L. (2006) Practice Based Research: A Guide. Retrieved from http://www. creativityandcognition.com/resources/PBR\%20Guide-1.1-2006.pdf at 27 March 2015.

COHEN, L. \& MANION, L. (1994) Research Methods in Education (4 ${ }^{\text {th }}$ Edn). New York: Routledge.

DALLY, K., HOLBROOK, A., GRAHAM, A. \& LAWRY, M. (2004) The processes and parameters of fine art PhD examination. International Journal of Educational Research, 41(2), 136-162.

DRAPER, P. \& HARRISON, S. (2010) Reflecting on reflection-in-action: Supervising practice-based doctorates in music. In L. Williams (Ed.), Proceedings of The 29th International Society for Music Education (ISME) World Conference (pp. 60-4). Perth WA: International Society for Music Education.

DRAPER, P. and HARRISON, S. (2011) Through the eye of the needle: The emergence of a practice-led research doctorate in music. British Journal of Music Education, 28(1), 87-102.

EVANS, S. (2014) Meeting at the Table of Time: A Creative Practice Enquiry Into Carnatic Jazz Intercultural Music. (Unpublished PhD Thesis). Macquarie University.

FENTON, D. (2007) Unstable Acts: A Practitioner's Case Study of the Poetics of Postdramatic Theatre and Intermediality. (Unpublished PhD Thesis). Queensland University of Technology.

FRANKLIN, G. (2001) Stylistic Features in the Recorded Improvisations of Herman 'Woody' Shaw (19441989). (Unpublished PhD Thesis). University of New South Wales.

FREEMAN, P. (2006) Eclecticism in the Music of Antônio Carlos Jobim: A Consideration of Stylistic Diversity. (Unpublished PhD Thesis). University of Queensland.

HAMILTON, J. \& JAANISTE, L. (2010) A Connective Model for the Practice-Led Research Exegesis: An analysis of content and structure. Journal of Writing in Creative Practice, 3(1), 31-44.

HARRISON, G. (1999) The Dialectics and Aesthetics of Freedom: Hegel, Slavery and African American Music. (Unpublished PhD Thesis). University of Sydney.

HAYWOOD, N. (2014) Complexity Through Interaction: An Investigation into the Spontaneous Development of Collective Musical Ideas from Simple Thematic materials. (Unpublished PhD Thesis). University of Tasmania.

HODGES, G. (2008) The Analysis of Jazz Improvisational Language and its Use in Generating New Composition and Improvisation: A Case Study Involving Bebop Jazz Guitarist Jimmy Raney (20/8/27 9/5/95). (Unpublished PhD Thesis). Macquarie University.

HOLGATE, G. (2014) Interactions in Improvised Music: People at Play. (Unpublished PhD Thesis). University of Sydney. 
KJØRUP, S. (2011) Pleading for Plurality: Artistic and Other Kinds of Research. In M. Biggs \& H. Karlsson (Eds.), The Routledge Companion to Research in the Arts (pp. 24-43). New York: Routledge.

MACLEOD, K. \& CHAPMAN, N. (2014) The absenting subject: Research notes on PhDs in fine art. Journal of Visual Art Practice, 13(2), 138-149.

MILECH, B. (2006) The critical artist. In E. Martin \& J. Booth (Eds.), Art-Based Research: A Proper Thesis (pp. 1-19). Altona, Victoria: Common Ground in association with Victoria University.

MILECH, B. \& SCHILO, A. (2004) 'Exit Jesus': Relating the exegesis and creative/production components of a research thesis'. Text, 3(April). Retrieved from http://www.textjournal.com.au/speciss/issue3/ milechschilo.htm at 21 May 2015.

PALTRIDGE, B., STARFIELD, S., RAVELLI, L. \& NICHOLSON, S. (2011) Doctoral writing in the visual and performing arts: Issues and debates. International Journal of Art \& Design, 30(2), 242-255.

PALTRIDGE, B., STARFIELD, S., RAVELLI, L. \& TUCKWELL, K. (2012) Change and stability: Examining the macrostructures of doctoral theses in the visual and performing arts. Journal of English for Academic Purposes, 11, 1-13.

RAVELLI, L., PALTRIDGE, B., STARFIELD, S., TUCKWELL, K. (2013) Extending the notion of 'text': The visual and performing arts doctoral thesis. Visual Communication, 12(4), 395-422.

STEVENS, T. (2000) The Origins, Development and Significance of the Red Onion Jazz Band, 1960-1996. (Unpublished PhD Thesis). University of Melbourne.

STEWART, D., ROOK, D. \& SHAMDASANI, P. (2007) Focus Groups: Theory and Practice (2 ${ }^{\text {nd }}$ Edn.) London: Sage Publications.

STOCK, C. (2009) Choreographing research: Supervising the dancing thesis. Text, 6(October), 1-15.

SUGG, A. (2001) Tracking the Trane: Comparing Selected Improvisations of John Coltrane, Jerry Bergonzi and David Liebman. (Unpublished PhD Thesis). University of Adelaide.

THOMAS, D. (2006) A general inductive approach for analyzing qualitative evaluation data. American Journal of Evaluation, 27(2), 237-246.

WHITEOAK, J. (1993) Australian Approaches to Improvisatory Musical Practice 1836-1970: A Melbourne Perspective. (Unpublished PhD Thesis). Latrobe University.

WILLIAMSON, P. (2013) Developing Technical Control, Ensemble Interactions and Flow in Jazz Performance. (Unpublished PhD Thesis). Monash University.

WILSON, J. (2011) Creative arts research: A long path to acceptance. Australian Universities Review, 53(2), $68-76$.

Christopher Coady (PhD, University of New South Wales) is a lecturer in Musicology at the Sydney Conservatorium of Music, the University of Sydney. He is author of the monograph John Lewis and the Challenge of 'Real' Black Music (University of Michigan Press) and is an active researcher of both historical and contemporary jazz practice.

Michael Webb is an ethnomusicologist (PhD, Wesleyan University) and currently serves as Chair of Music Education at the Sydney Conservatorium of Music, the University of Sydney. Besides publishing on Pacific ethnomusicology his articles have appeared in Music Education Research, International Journal of Music Education and as a co-author, in the Oxford Handbook of Music Education. 